\title{
Documentation of Triglav glacier, Slovenia, using non-metric panoramic images
}

\author{
Mihaela TRIGLAV-ČEKADA, ${ }^{1}$ Matej GABROVEC ${ }^{2}$ \\ ${ }^{1}$ Geodetic Institute of Slovenia, Ljubljana, Slovenia \\ E-mail: mihaela.triglav@gis.si \\ ${ }^{2}$ Anton Melik Geographical Institute, Scientific Research Centre of the Slovenian Academy of Sciences and Arts, \\ Ljubljana, Slovenia
}

\begin{abstract}
Triglav glacier is situated on the northeast side of the highest Slovenian mountain peak, Triglav; it is a glacier remnant of the Little Ice Age. Next to Triglav glacier is the Kredarica mountain hut with a meteorological station. At $2514 \mathrm{~m}$ a.s.l., it is the highest meteorological station in Slovenia, and has been in continuous operation since 1954. In this paper, the acquisition of three-dimensional data from archived, non-metric, panoramic, Horizont images is presented. The annual variations of Triglav glacier's area are given for the period 1976-2010, together with monthly snow variations for the years 1977 and 1998. Additionally, theoretical and empirical volumes and an empirical thickness reduction are computed. The changes to Triglav glacier are compared with the summarized meteorological data from the Kredarica meteorological station. In 1976 Triglav glacier covered an area of 15 ha; by 1992 this had shrunk to $4.3 \mathrm{ha}$, and it reached its minimum of $0.6 \mathrm{ha}$ in 2003, as measured from Horizont images. Since then the glacier has been mainly conserved by the snow cover from previous winters.
\end{abstract}

\section{INTRODUCTION}

Glaciers can be used as key indicators of climate change (Kuhn, 1981; Haeberli and others, 2007; Raper and Braithwaite, 2009). Additionally, alpine glaciers play an important role in the alpine hydrological system (Chen and Ohmura, 1990; Lambrecht and Kuhn, 2007). In alpine countries with many glaciers, various glacier inventories have been made to study the glaciers' losses in overall area and volume (Kääb and others, 2002; Citterio and others, 2007; Lambrecht and Kuhn, 2007; Abermann and others, 2009). However, detailed studies of glaciers that involve determining their mass-balance behaviour are rare, having been made for just a few of the larger alpine glaciers (e.g. Thibert and others, 2008; Fischer, 2010). To be able to completely understand a given glacier's responses to climate variations, all sizes of glaciers have to be studied. UNESCO/IASH (1970) stated that glaciers smaller than $0.5 \mathrm{~km}^{2}$ represent the smallest glaciers, while Kuhn (1995) refers to the representatives of this area class as very small glaciers. Only a few studies of very small glaciers have been made in various parts of the world (Kuhn, 1994; Kaufmann and Ladstädter, 2008; DeBeer and Sharp, 2009; Grunewald and Scheithauer, 2010; Shahgedanova and others, 2012).

Triglav glacier lies beneath the top of Slovenia's highest mountain peak, Triglav $(2864 \mathrm{~m})$, located in the Julian Alps. It is situated on the mountain's northeast side at an altitude of $2400-2500 \mathrm{~m}$. It lies below the climatic snowline of the Julian Alps, which is taken as $2700 \mathrm{~m}$ (Gams, 1994). According to Kuhn (1995), Triglav glacier can be classified as a very small glacier. According to the UNESCO/IASH (1970) primary classification it is currently a mountain glacier in the form of an ice apron. Until the 1950s Triglav glacier was still showing signs of movement in the form of glacier crevasses (Meze, 1955; Triglav-Čekada and others, 2012).

The Kredarica mountain hut was constructed next to the glacier in 1896. The glacier retreat can therefore be traced back through the whole of the 20th century using old drawings and several amateur photographs.
Systematic, annual measurements of Triglav glacier began in 1946, carried out by the Anton Melik Geographical Institute of the Scientific Research Centre of the Slovenian Academy of Sciences and Arts, and were made manually using a metre band, rope and compass to measure the distance and direction towards permanent points marked on rocks around the glacier. Some non-metric images were also taken during these expeditions. Regular, monthly photographing of the glacier began in 1976 using a panoramic, non-metric Horizont camera (Fig. 1).

The Kredarica mountain hut contains the highest meteorological station in Slovenia, and has been in constant operation since 1954. At first, the weather conditions were monitored three times per day by permanent meteorological staff on Kredarica. However, 24 hour per day observations were introduced in April 1991, and since 1994 automatic measuring instruments have been in use. Earlier meteorological observations at Kredarica were conducted between 1897 and 1912, but only during the summer months (Cegnar and Roškar, 2004).

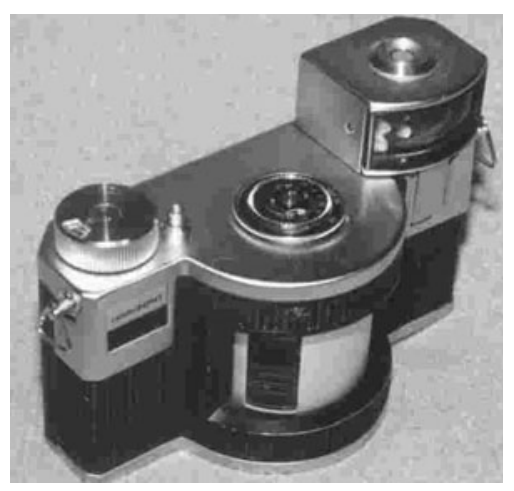

Fig. 1. The panoramic Horizont camera. The camera uses ordinary, $35 \mathrm{~mm}$ film, with a frame size of $24 \mathrm{~mm} \times 58 \mathrm{~mm}$. It has a $120^{\circ}$ field of view and a theoretical focal length of $28 \mathrm{~mm}$. 


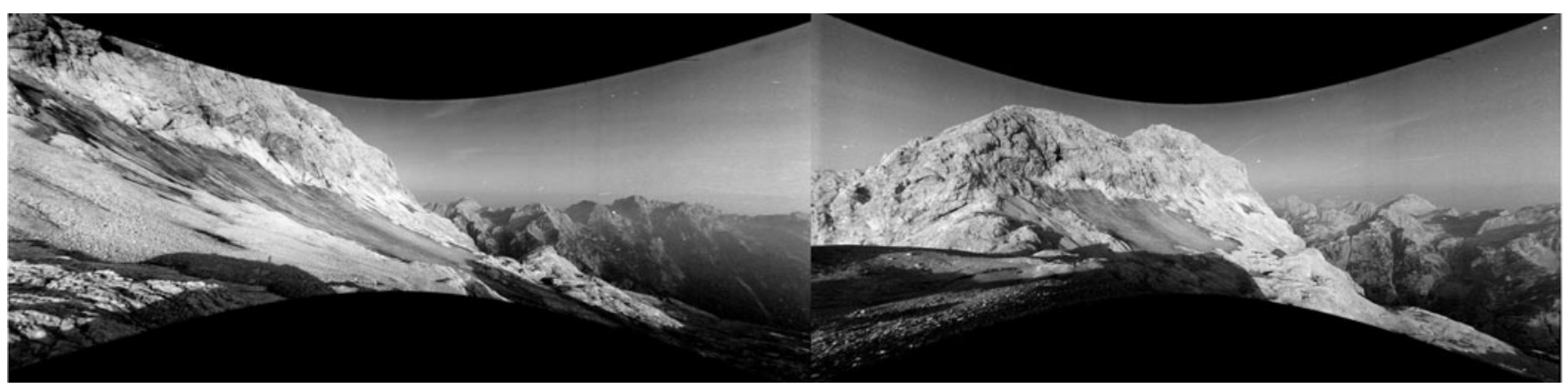

Fig. 2. Re-sampled Horizont images from the two standard standpoints taken on 24 August 1989. On the left image, standpoint A, the white rocks above the glacier that represent the historical upper boundary of the glacier can be clearly seen. The right image was taken from standpoint B.

Triglav glacier is an ideal example for studying the retreat of a very small glacier and meteorological measurements that can show long-term, climate variations. The first studies of Triglav glacier's response to climatic variations were made by Gams (1994), Gabrovec and Zakšek (2007) and Gabrovec (2008). In the current work, the annual variations in area and volume over the past 35 years and monthly variations in the snow-cover elevation are presented and compared with the meteorological data. The results obtained from Triglav glacier studies will also help to elucidate the behaviour of other very small glaciers in the Alps and southeast Europe (e.g. glaciers in Montenegro, Albania and Bulgaria; Grunewald and others, 2006; Hughes, 2007, 2009; Grunewald and Scheithauer, 2010).

\section{METHODS}

In addition to the systematic, annual measurements, some non-metric images of the glacier were taken from different locations using a variety of cameras. However, to enable measurement of the glacier's retreat, it was necessary to have photographs from identical standpoints over the years. Initially, some approximate standpoints for the annual photographing of Triglav glacier using different cameras were used (Meze, 1955; Šifrer,1963; Šifrer and Košir, 1976; Gabrovec, 2008; Triglav-Čekada and others, 2012).

For regular, monthly photographing of the glacier, a Horizont non-metric camera mounted on two fixed standpoints was chosen. Both standpoints make it possible to cover the whole glacier within the view of a single photograph and are easily accessible from the Kredarica mountain hut. Unfortunately, the views of the glacier from these two standpoints are convergent, preventing any stereo-vision from the two images (Fig. 2). The standpoints are stabilized using metal bars $\sim 1 \mathrm{~m}$ high with a small horizontal plate on top to hold the camera.

The Horizont panoramic camera is kept at the Kredarica mountain hut and used only for the monthly photographs of the glacier. It uses a swing lens to produce the panoramic image. The film in a swing-lens, panoramic camera is placed on a cylinder and is exposed through a small moving slit. Therefore, its mathematical projection model is different to the usual perspective projection applied in standard photogrammetric procedures. In the process of calibration we developed a special geometrical model of the projection, used to perform a re-sampling of the panoramic image to a correct perspective projection (Triglav-Čekada and others, 2011).

The first geodetic measurements of Triglav glacier were conducted in 1952. They included measurements of the glacier boundary and the points that made it possible to produce contour presentations of the glacier. The second set of geodetic measurements was conducted in 1995 (Gabrovec, 1998). Since 1999, regular geodetic and photogrammetric measurements of the glacier have been made, and until 2007 both aerial and ground-based oblique photogrammetric measurements were made on a biennial basis (Triglav-Čekada, 2007). Due to the small size of the glacier in the past decade, since 2007 annual geodetic measurements of the glacier boundary and the points on the surface of the glacier, which are arranged in vertical lines, have been conducted. In combination with the geodetic measurements, only supplementary, ground-based, oblique, photogrammetric measurements are conducted. In 1999 and 2000, ground-penetrating radar (GRP) surveys of the glacier were also performed, to measure the depth of the glacier (Verbič and Gabrovec, 2002).

In this research we present a comparison of the threedimensional (3-D) boundaries of Triglav glacier acquired from Horizont images. The interactive method of absolute orientation, described in detail by Triglav-Čekada and others (2011) and Rönnholm and others (2003) was used. First, the Horizont images were re-sampled to the perspective projection (Fig. 2). Then the same images were used in an interactive method for absolute orientation. The absoluteorientation parameters of the image (the 3-D location of the standpoint, the three angles of the image orientation and the scale) were derived with a manual interactive search for the best fit of the superimposed 3-D points of the digital elevation model (DEM) onto the details seen on the image. When the image is oriented correctly, the superimposed DEM points fit the image well. The 3-D boundary of the glacier is measured by selecting individual 3-D points from the superimposed DEM. The glacier boundary (i.e. the glacier edge) lies on bare, rocky terrain. This terrain can be described by the DEM measured at any time between 1976 and 2012, as it is assumed it has not changed significantly during this period. Therefore, we used a modern, photogrammetrically derived DEM with a grid size of $2 \mathrm{~m} \times 2 \mathrm{~m}$ from 2005. Unfortunately, this decision caused problems, as the theoretical volumes of the glacier became negative after 2005.

The delineation of the glacier boundary based on Horizont images also includes the snow adjoining the glacier, as 
such snow areas cannot be visually distinguished from the real glacier. Such a glacier delineation was also proposed by UNESCO/IASH (1970). Because the annual systematic measurements made prior to 1976 show glacier areas smaller than 15 ha, it was decided that the lower tongue of the snow cover seen in the Figure 3 images from 1976 and 1980 should be excluded from the glacier area. As the extent of the snow cover from previous winters at the end of the glacier's melting season could be relevant for a comparison with the meteorological parameters, it was decided that these data should also be presented. For the empirical computations (Table 1) the reduced areas were also computed. The reduced areas present the area in 1976 without a lower snow tongue, and in subsequent years they obey the rule that the glacier cannot grow in size for two successive years.

The resulting 3-D glacier boundary is used to calculate the 2-D area and the theoretical 3-D volume of the glacier. The glacier's 2-D area is measured as a projection of a 3-D boundary on a plane with an elevation of $0 \mathrm{~m}$. The glacier's theoretical 3-D volume is calculated as the difference between two surfaces: the upper surface connects the 3-D glacier boundary, while the lower surface connects the points of the DEM from 2005.

It was concluded that more precise glacier-area measurements could be expected if the Horizont images from standpoint B were used (Fig. 2), as the view towards the glacier is more uniform for all the parts of the glacier (Triglav-Čekada and others, 2011). An expected average standard deviation of the area of \pm 0.06 ha and the volume of $\pm 5.5 \times 1000 \mathrm{~m}^{3}$ can be expected if angle-orientation errors of $\pm 0.2^{\circ}$ for all three angles are allowed. (The Horizont images from standpoint $A$ have a more inclined view towards the glacier, which results in greater standard deviations of the area and volume when applying the same angleorientation errors.)

The theoretical volume calculations were checked against the empirical volume calculations proposed by Chen and Ohmura (1990):

$$
V=28.5 S^{1.357},
$$

where $S$ is the reduced area size. Due to the lack of multiannual, ground-penetrating radar measurements, which would tell us more about the glacier-thickness reduction, only the empirical mean thickness, $h$, of the glacier could be calculated by Chen and Ohmura (1990):

$$
h=28.5 S^{0.357} \text {. }
$$

Horizont images can also be used to study the monthly variation of snow cover on the glacier. As our method enables only the 3-D restitution of objects that are located on the DEM, only the upper boundary of the glacier can be measured from the Horizont images. The upper boundary of the glacier leans against steep rocks, which always show a snow/rock contact (see Fig. 6). The interactive orientation, therefore, enables a study of the average glacier upperboundary elevation during different months.

\section{RESULTS}

\section{Annual variation}

In 1937 the glacier had an area of 27 ha, as determined from a 1937 topographic map with a scale of $1: 25000$. At the beginning of the regular measurements using a metre band in 1946, the glacier area had reduced to 14.4 ha, or
15.7 ha when the snowfields were included Meze, 1955). In the period 1946-73 the glacier retreated only slightly. The uncovered glacier had an area of 11.9 ha in 1973, as measured by metre band (Šifrer and Košir, 1976).

If the glacier is covered by snow from the previous winter, only the extended glacier area with snowfields included can be acquired from the Horizont images. Therefore, the size of the snow-covered glacier acquired from the Horizont images is greater than the size of the real glacier obtained from the metre-band measurements in the period 1946-73. In the period 1976-82 the glacier was still covered by snow from the previous winter at the end of September (upper two images in Fig. 3). Accelerated glacier retreat began in 1983, with the glacier being mainly snow-free at the end of the melting season. Over the next 10 years the glacier area decreased from 10.1 ha in 1983 to 4.7 ha in 1993 . In 1995 it reached 3.0 ha, and over the next 5 years it decreased to 1.1 ha by 2000 (bottom image of Fig. 3). It reached its minimum of 0.6 ha in the period 2003-07, with the exception of 2004, 2005 and 2006, when the snowcovered glacier was a little larger.

As a result of the above-mentioned snow-rich winters, the retreat of the glacier has halted since 2007/08. The glacier was still partly conserved under the snow when the annual geodetic measurements in late August or early September were conducted in the years 2009-11. The latest geodetic measurements show 2.4 ha of snow-covered glacier area in 2011. This means that the Horizont images from the end of September or early October reveal smaller snow-covered glacier areas than the areas acquired by the geodetic measurements. The differences between the geodetic measurements in late August/early September and the Horizont images in late September show an average reduction of the snow-covered glacier area of 0.2 ha in the period 2008-10. The geodetic measurements are conducted in mid-September at the latest, i.e. before the first autumn snow, which can cover the glacier. Nevertheless, they are very important as they enable detailed glaciersurface studies, which are not possible from only the Horizont images.

As seen in Figures 4 and 5, the glacier-area retreat is exponential for the period 1976-2010. For the period 19712000 the average annual and average summer temperatures on Kredarica are -1.3 and $5.3^{\circ} \mathrm{C}$, respectively (Cegnar and Roškar, 2004). In Figure 4 we see a small increase in the average annual air temperature and a slightly larger increase in the average summer air temperature (JuneAugust). Additionally, it is clear that before 1990 the mean annual and the mean summer air temperatures are generally lower than the long-term average, while after 1990 they are mainly higher.

The maximum snow-cover depth in June is very important for the glacier's conservation, as it presents the highest snow-cover depth at the end of the glacier-accumulation period. Figure 5 shows the general trend for the reduction of the annual and the June maximum snow-cover depth. Both maximum snow-cover depths are correlated, and this trend is also correlated with glacier reduction. In the period 1993-2000 the June maximum snow-cover depths are much smaller than the average greatest maximum snow-cover depths, which mainly occur in April. This can depend on higher spring temperatures, which also raise the average annual temperatures (Fig. 4) and melt away the snow accumulation from previous months. 


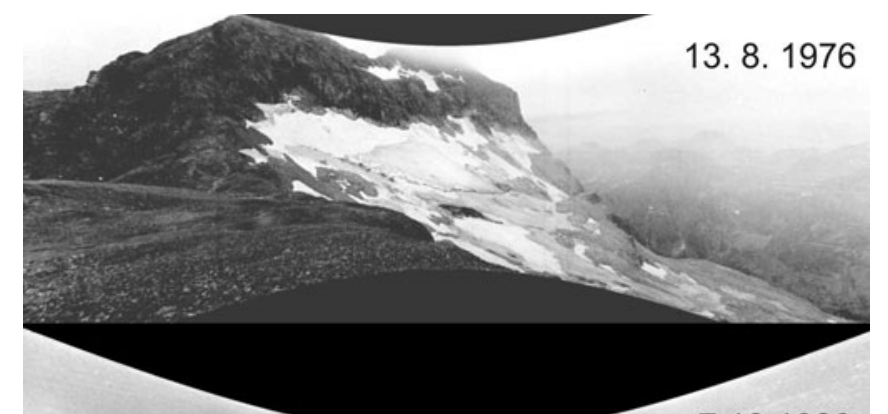

7.10.1980
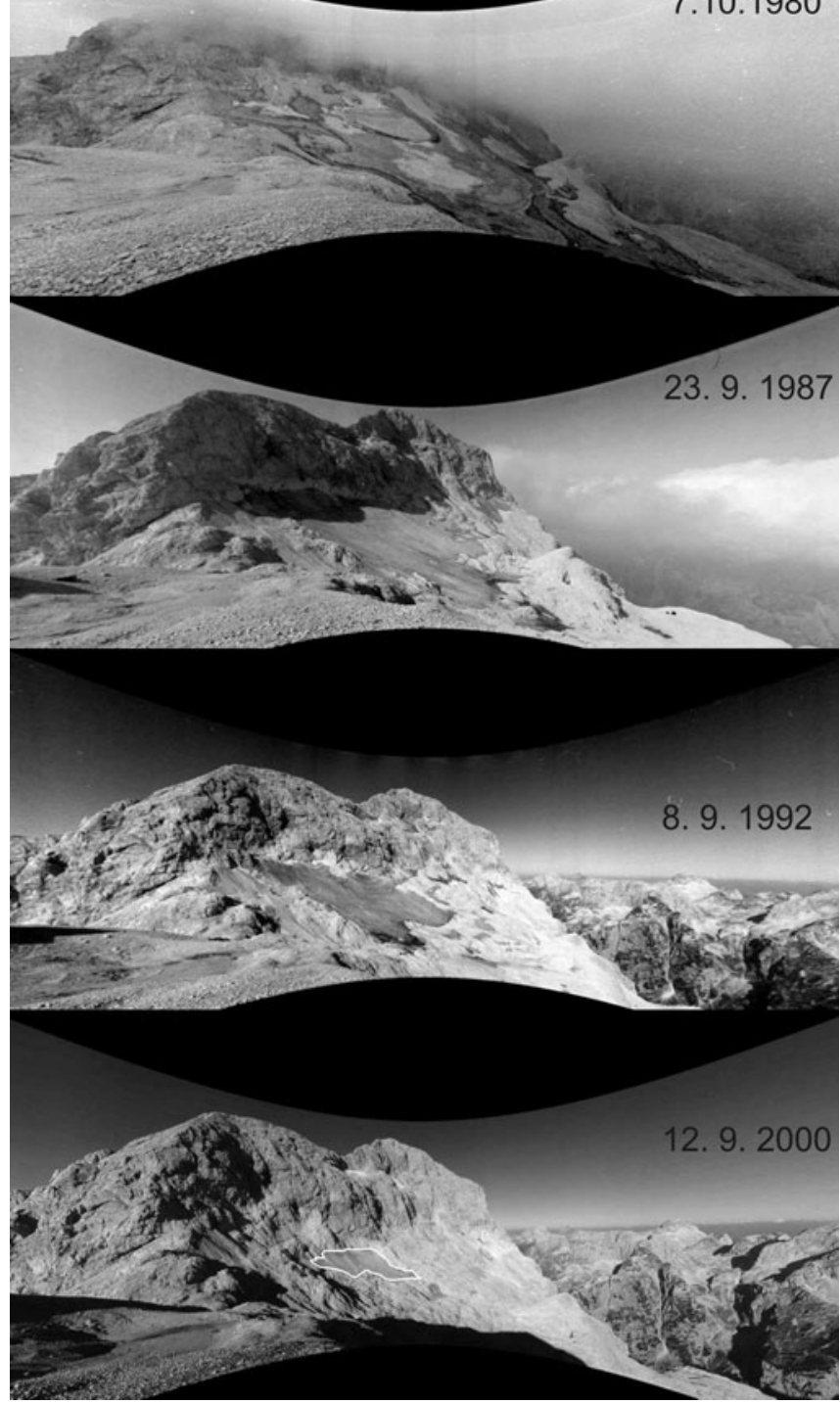

Fig. 3. The retreat of Triglav glacier on re-sampled Horizont images. Dates are day/month/year. Because in 2000 the glacier/rock contrast is very small, the boundary of the glacier in that image is marked with a white border.

The second highest maximum snow-cover depth was observed in 1977, with $690 \mathrm{~cm}$ of snow in April. The period 1975-79 is recorded as the period of the highest maximum snow-cover depth since the start of the meteorological observations on Kredarica in 1954 (Nadbath, 1999). The next exceptional year was 2001, with $700 \mathrm{~cm}$ of snow. However, it was followed by just 195 and $240 \mathrm{~cm}$ maximum snowcover depth in 2002 and 2003, respectively. In 2003 this was accompanied by exceptionally high summer temperatures (Fig. 4). These unfavourable conditions resulted in the

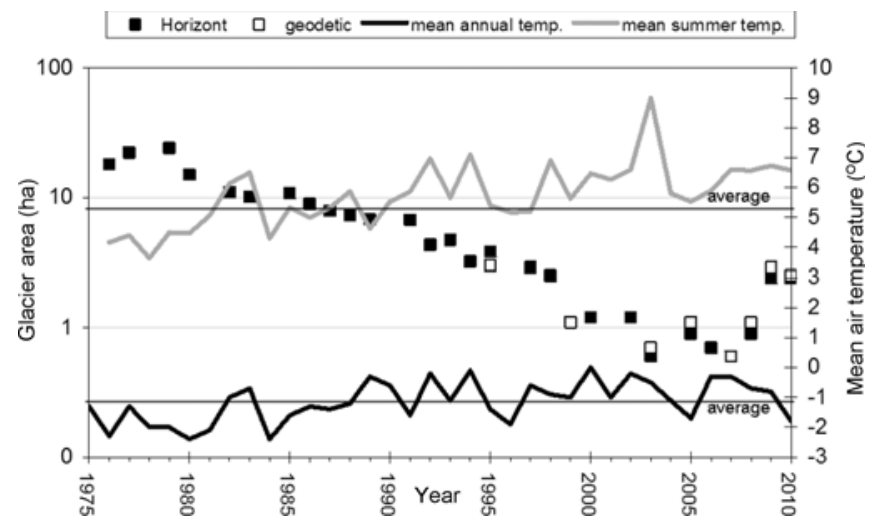

Fig. 4. Area change of Triglav glacier on a logarithmic scale on the left-hand axis. The mean annual and the mean summer temperatures (June-August) on the right-hand axis. The temperatures are taken from Cegnar and Roškar (2004) and the newest data of the Slovenian Environment Agency (http://www.arso.gov.si/en/).

smallest size of the glacier in 2003, when it was just 0.6 ha on the Horizont image from early October.

Since 2003 the annual maximum snow-cover depth has been increasing again, resulting in a conserved glacier under the snow during the summer months. Only the lateSeptember Horizont images reveal a snow-free glacier of 0.6 ha in the years 2003-07. Later, in 2009 and 2010, the Horizont images also show a snow-covered glacier in mid-September. It can be concluded that the maximum snow-cover depth represents an important factor for glacier conservation. Unless such snowy winters continue, the glacier will soon disappear.

An estimate of the glacier area under the snow is given as the reduced area in Table 1, which was estimated as described in the Methods section. The reduced area was used to calculate the empirical volume and the empirical mean thickness of the glacier. It is clear that the theoretical volumes derived from the 3-D glacier boundaries describing, in many cases, a still partially snow-covered glacier, are in good correlation with the empirical volume derivations. On 5/6 July 2000 the only useful glacier-thickness measurements

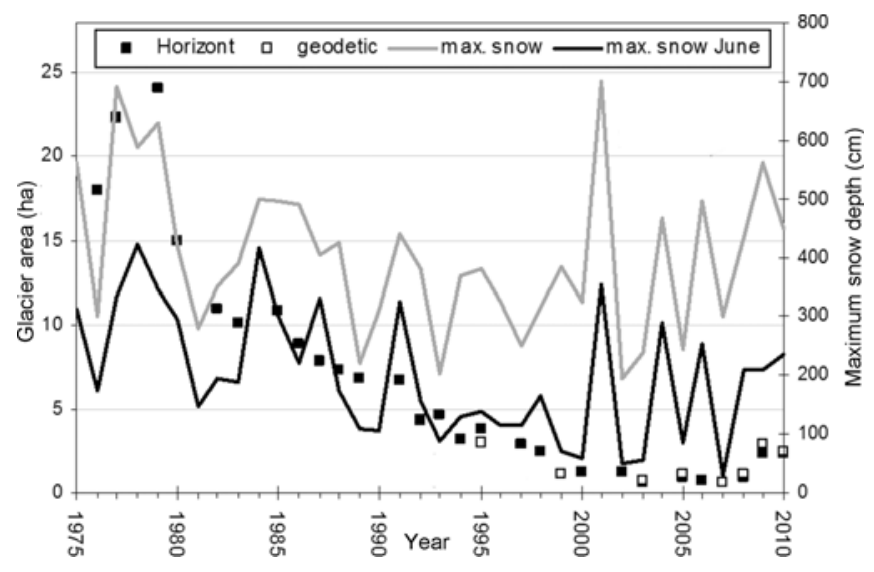

Fig. 5. Area change of Triglav glacier on the left-hand axis. The annual maximum snow-cover depth and the maximum snowcover depth in June on the right-hand axis are taken from Cegnar and Roškar (2004) and the Slovenian Environment Agency (http://www.arso.gov.si/en/). 
Table 1. Area, reduced area and theoretical volume from Horizont images, and empirical volume and empirical average thickness (as defined by Chen and Ohmura, 1990). For the computation the reduced area is used

\begin{tabular}{|c|c|c|c|c|c|}
\hline \multirow[t]{3}{*}{ Year } & \multicolumn{3}{|c|}{ Horizont } & \multicolumn{2}{|c|}{ Empirical } \\
\hline & Area & $\begin{array}{l}\text { Reduced } \\
\text { area }\end{array}$ & $\begin{array}{c}\text { Theoretical } \\
\text { volume }\end{array}$ & Volume & $\begin{array}{l}\text { Average } \\
\text { thickness }\end{array}$ \\
\hline & ha & ha & $10^{3} \mathrm{~m}^{3}$ & $10^{3} \mathrm{~m}^{3}$ & $\mathrm{~m}$ \\
\hline 1976 & 18.0 & 15.0 & 1408.0 & 2171.7 & 14.5 \\
\hline 1977 & 22.3 & 15.0 & 2210.0 & 2171.7 & 14.5 \\
\hline \multicolumn{6}{|l|}{$1978^{*}$} \\
\hline 1979 & 24.1 & 15.0 & 2149.0 & 2171.7 & 14.5 \\
\hline 1980 & 15.0 & 15.0 & 1978.0 & 2171.7 & 14.5 \\
\hline \multicolumn{6}{|l|}{$1981^{*}$} \\
\hline 1982 & 11.0 & 11.0 & 997.0 & 1425.7 & 13.0 \\
\hline 1983 & 10.1 & 10.1 & 967.0 & 1269.7 & 12.6 \\
\hline \multicolumn{6}{|l|}{$1984^{*}$} \\
\hline 1985 & 10.8 & 10.1 & 901.0 & 1269.7 & 12.6 \\
\hline 1986 & 8.9 & 8.9 & 786.0 & 1069.5 & 12.0 \\
\hline 1987 & 8.0 & 8.0 & 716.0 & 925.4 & 11.6 \\
\hline 1988 & 7.3 & 7.3 & 649.0 & 817.3 & 11.2 \\
\hline 1989 & 6.8 & 6.8 & 554.0 & 742.3 & 10.9 \\
\hline \multicolumn{6}{|l|}{$1990^{*}$} \\
\hline 1991 & 6.7 & 6.7 & 341.0 & 727.5 & 10.9 \\
\hline 1992 & 4.3 & 4.3 & 356.0 & 398.5 & 9.3 \\
\hline 1993 & 4.7 & 4.3 & 314.7 & 398.5 & 9.3 \\
\hline 1994 & 3.2 & 3.2 & 212.0 & 266.9 & 8.3 \\
\hline $1995^{\dagger}$ & 3.0 & 3.0 & 211.7 & 266.9 & 8.2 \\
\hline \multicolumn{6}{|l|}{ 1996* } \\
\hline 1997 & 2.9 & 2.9 & 107.8 & 233.5 & 8.1 \\
\hline 1998 & 2.5 & 2.5 & 109.0 & 190.9 & 7.6 \\
\hline $1999^{\dagger}$ & 1.1 & 1.1 & 60.0 & 70.5 & 5.7 \\
\hline $2000^{\ddagger}$ & 1.2 & 1.1 & 35.0 & 70.5 & 5.7 \\
\hline \multicolumn{6}{|l|}{$2001^{*}$} \\
\hline 2002 & 1.2 & 1.1 & 22.0 & 27.5 & 5.7 \\
\hline 2003 & 0.6 & 0.6 & 5.9 & 27.5 & 4.6 \\
\hline \multicolumn{6}{|l|}{$2004^{*}$} \\
\hline 2005 & 0.9 & 0.6 & 5.8 & 27.5 & 4.6 \\
\hline 2006 & 0.7 & 0.6 & & 27.5 & 4.6 \\
\hline $2007^{\dagger}$ & 0.6 & 0.6 & & 27.5 & 4.6 \\
\hline 2008 & 0.9 & 0.6 & & 27.5 & 4.6 \\
\hline 2009 & 2.4 & 0.6 & & 27.5 & 4.6 \\
\hline 2010 & 2.4 & 0.6 & & 27.5 & 4.6 \\
\hline $2011^{\dagger}$ & 2.4 & 0.6 & & 27.5 & 4.6 \\
\hline
\end{tabular}

*No good standpoint B images available at end of melting season.

$\dagger$ Area measured by geodetic measurements.

¥Theoretical volume estimated from glacier-thickness measurements.

were recorded with GPR (Verbič and Gabrovec, 2002). The thickness of the snow cover on the glacier and the ice thickness were given separately. The maximum ice thickness of the glacier was $9.5 \mathrm{~m}$. Additional snow cover over the glacier, in most cases, did not exceed $1 \mathrm{~m}$. Using these data, a glacier volume of $\sim 35000 \mathrm{~m}^{3}$ was calculated. The volume calculated from the thickness measurements is smaller than the volume computed empirically, $70500 \mathrm{~m}^{3}$. Nevertheless, the theoretical volumes correspond better to the empirical volumes. The difference between the theoretical volume and the empirical volume in 2005 implies a negative theoretical volume, as discussed above.

The empirical mean thickness of $5.7 \mathrm{~m}$ derived for 2000 also corresponds well, in general, with the thickness span of the GPR measurements from 2000. Therefore, the empirical thickness values can be taken for the computation of

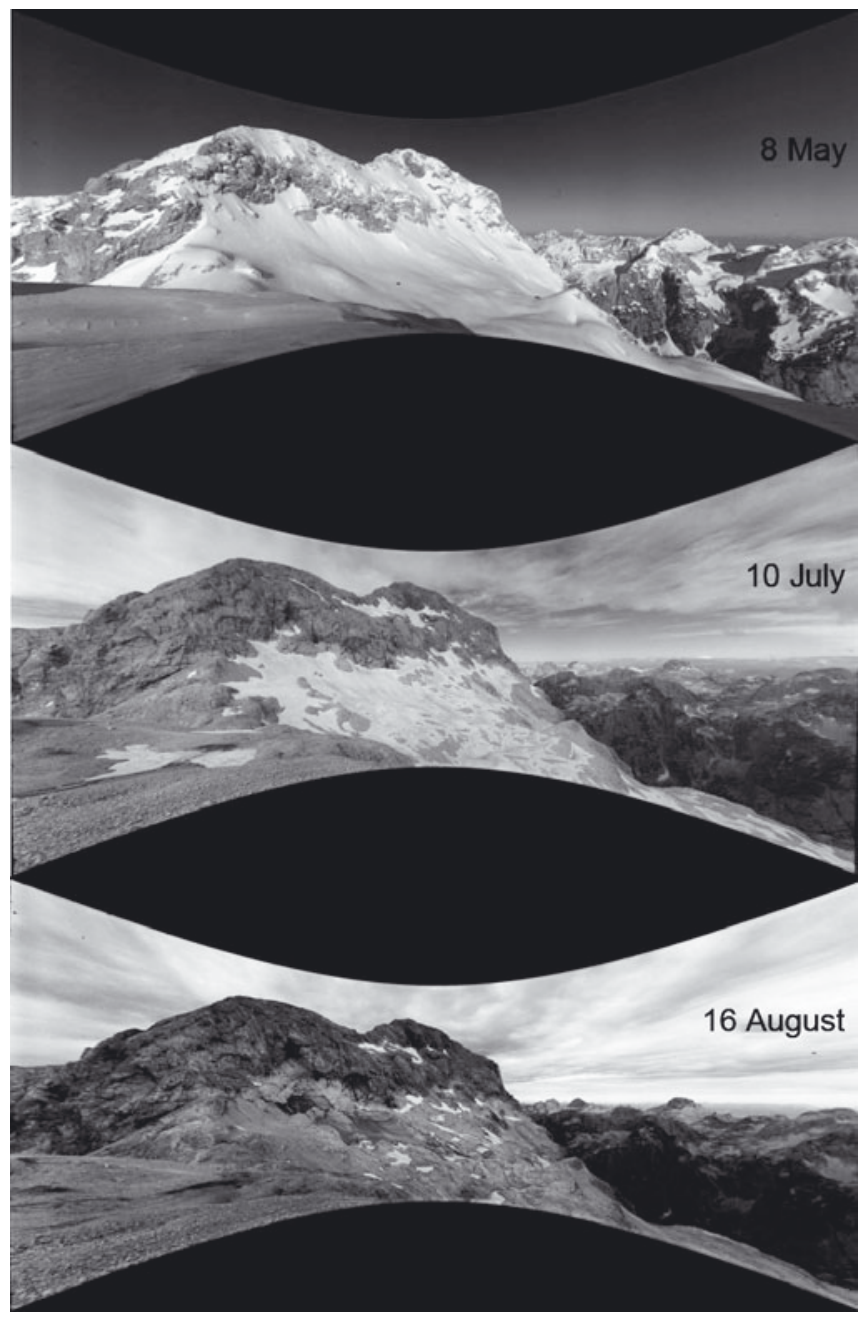

Fig. 6. Triglav glacier's upper-boundary elevation reduction between May and August 1998. In May the snow reaches to the top of the light-grey rocks seen in the August image.

the annual glacier-thickness reduction. On average, the glacier thickness has reduced by $0.5 \mathrm{ma}^{-1}$ in the period 1976-2011.

\section{Monthly variation}

The average upper boundary of the glacier covered by snow (which leans against steep rocks; Fig. 6) can give an indication of the glacier's thickness reduction. This can be directly compared with the maximum snow-cover depth observations at Kredarica. Years 1977 and 1998 were chosen to test the monthly snow-cover variation.

On average, Kredarica is snow-covered for $73 \%$ of the year. In the summer months there are, on average, only a couple of days with snow cover. The 1971-2000 longterm average at Kredarica shows that we can expect the highest maximum snow-cover depths in April, which is also characterized as the rainiest month in the lowlands. March, April and May are characterized as the months with the highest maximum snow-cover depths (Cegnar and Roškar, 2004). This can be clearly seen in Figure 7. As expected, the average upper-boundary elevation of the glacier covered by snow corresponds well with the maximum snow-cover depth observations. The elevation difference between the 1977 and the 1998 average upper boundary is $17 \mathrm{~m}$ in August and $16 \mathrm{~m}$ in May. The difference between March 1977 and 


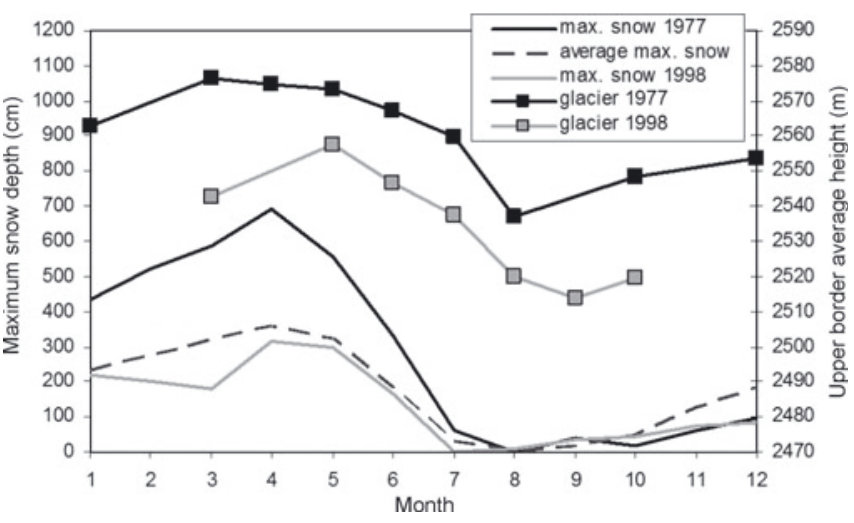

Fig. 7. The maximum snow-cover depth per month in 1977 and 1998 on the left-hand axis. The average upper-boundary elevation of the glacier covered by snow in different months for 1977 and 1998 on the right-hand axis.

May 1998, in which the highest average upper-boundary elevation is seen, is $19 \mathrm{~m}$ in elevation and $19 \mathrm{~m}$ in planimetry. The differences are rounded up to the nearest $1 \mathrm{~m}$, due to greater expected inaccuracies of the interpolated DEM in steeper terrain.

The maximum elevation difference in 1 year is $40 \mathrm{~m}$ for 1977, between March and August, and $44 \mathrm{~m}$ for 1998, between May and September. These elevation differences show that on the upper boundary of the glacier there is a very thick accumulation of winter snow. In addition, this snow does not melt away as quickly as the snow on Kredarica, as it is protected by the shadow of Triglav mountain. The meteorological station on Kredarica is, in contrast, positioned in the open and is liable to high winds and melting snow on sunny days. Therefore, the shadow of Triglav mountain represents an important conserving factor for the glacier.

In Figure 8 the highest elevations of the glacier's upper boundary for 1977 and 1998 are drawn on a summer Horizont image of 26 August 1977. It is clear that the upper glacier boundary in May 1998 corresponds well with the upper summer glacier boundary in 1977, which is presented on the original Horizont image.

\section{CONCLUSION}

Regular monthly photographing of Triglav glacier, carried out since 1976 using a Horizont, panoramic, non-metric camera, represents an invaluable source of data, showing the snow conditions and glacier decrease over three decades. Annual geodetic and photogrammetric measurements of Triglav glacier have been available since 1999, while the Horizont images from the same period help us to resolve the minimum size of the glacier during the years when geodetic measurements were made on the glacier while it was still partly snow-covered.

The comparison of the annual glacier decrease with the average annual and summer temperatures and the maximum snow-cover depth at the nearby Kredarica meteorological station shows that the glacier decrease and conservation mainly depend on the maximum snow-cover depth in that year, especially the cover in June. The snow-rich winters from 2003 onwards prevented the glacier from disappearing. However, if the winter weather conditions are not favourable,

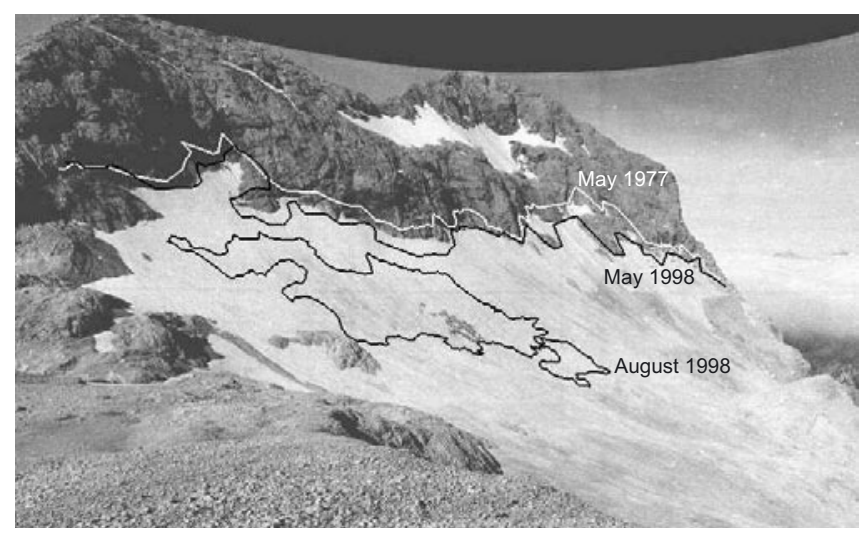

Fig. 8. Triglav glacier on 26 August 1977. The white curve represents the glacier's upper-boundary elevation in May 1977. The black curves represent the glacier's area in August 1998 and its highest upper-boundary elevation in May 1998.

with small maximum snow-cover depths, the complete disappearance of the glacier can be expected in the next few years.

As shown using an example of a monthly study in 1977 and 1998, the Horizont images enable a detailed study of the snow conditions on the glacier. The average upper-boundary elevation of the glacier covered by snow can be measured from Horizont images and compared with meteorological data from Kredarica. An annual elevation difference of $40 \mathrm{~m}$ for 1977 and $44 \mathrm{~m}$ for 1998 shows that on the upper boundary of the glacier there is a substantial accumulation of winter snow, which does not melt away as quickly as the snow at the meteorological station on Kredarica. This agrees very well with the Kuhn (1995) suggestion that very small glaciers owe their existence mainly to the local topographic features, which can cause wind drift and avalanches that locally multiply the winter precipitation by a larger factor. This method of monthly study for the upper-boundary elevation can be implemented for the whole period 19762010 and represents great potential for a detailed study of glacier shrinkage.

The interactive orientation of the DEM to a 2-D image will allow us to acquire further 3-D data from other archive images of Triglav glacier, which are stored in the archives but have not yet been analysed. This will enable a reconstruction of the glacier's size and snow conditions during earlier times. The method would benefit in terms of precision if a more accurate lidar-derived DEM were to be used in the future. The final goal for our future research is to study the mass balance of the glacier. The area and volume changes represent a basis for computing the geodetic mass balance, as proposed by Fischer (2011). To make these computations possible, some ice-density measurements of Triglav glacier will be needed prior to its disappearance.

\section{ACKNOWLEDGEMENTS}

This work was partly supported by Slovenian Research Agency projects L6-7136(C) and Z2-4182(B). We are grateful to $M$. Kuhn for confirming our theoretical volume calculations and pointing us in the direction of literature discussing very small glaciers. 


\section{REFERENCES}

Abermann J, Lambrecht A, Fischer A and Kuhn M (2009) Quantifying changes and trends in the glacier area and volume in the Austrian Öztal Alps (1969-1997-2006). Cryosphere, 3(2), 205-215 (doi: 10.5194/tc-3-205-2009)

Bahr DB and Radić V (2012) Significant contribution to total mass from very small glaciers. Cryosphere, 6(4), 763-770 (doi: 10.5194/tc-6-763-2012)

Cegnar T and Roškar J (2004) Meteorološka postaja Kredarica 1954-2004. Ministrstvo za okolje, prostor in energijo. Agencija Republike Slovenije za okolje, Ljubljana

Chen J and Ohmura A (1990) Estimation of Alpine glacier water resources and their change since the 1870s. IAHS Publ. 193 (Symposium at Lausanne 1990 - Hydrology in Mountainous Regions), 127-135

Citterio M and 6 others (2007) The fluctuations of Italian glaciers during the last century: a contribution to knowledge about Alpine glacier changes. Geogr. Ann. A, 89(3), 167-184 (doi: 10.1111/ j.1468-0459.2007.00316.x)

DeBeer CM and Sharp MJ (2009) Topographic influences on recent changes of very small glaciers in the Monashee Mountains, British Columbia, Canada. J. Glaciol., 55(192), 691-700 (doi: 10.3189/002214309789470851)

Fischer A (2010) Glaciers and climate change: interpretation of 50 years of direct mass balance of Hintereisferner. Global Planet. Change, 71(1-2), 13-26 (doi: 10.1016/j.gloplacha.2009.11.014)

Fischer A (2011) Comparison of direct and geodetic mass balances on a multi-annual time scale. Cryosphere, 5(1), 107-124 (doi: 10.5194/tc-5-107-2011)

Gabrovec M (1998) Triglavski ledenik med letoma 1986 in 1998 [The Triglav glacier between 1986 and 1998]. Geogr. Zbornik, 38(1), 89-110

Gabrovec M (2008) Il ghiacciaio del Triglav (Slovenia) = The Triglav glacier: ghiacciai montani e cambiamenti climatici nell' ultimo secolo. Terra Glacialis, Special issue, 75-87

Gabrovec M and Zakšek K (2007) Krčenje Triglavskega ledenika v luči osenčenosti. Dela, 28, 197-206

Gams I (1994) Changes of the Triglav glacier in the 1955-94 period in the light of climatic indicators. Geogr. Zbornik, 34, 81-117

Grunewald K and Scheithauer J (2010) Europe's southernmost glaciers: response and adaptation to climate change. J. Glaciol., 56(195), 129-142 (doi: 10.3189/002214310791190947)

Grunewald K, Weber C, Scheithauer J and Haubold F (2006) Mikrogletscher im Piringebirge (Bulgarien). Z. Gletscherkd. Glazialgeol., 39, 99-114

Haeberli W, Hoelzle M, Paul F and Zemp M (2007) Integrated monitoring of mountain glaciers as key indicators of global climate change: the European Alps. Ann. Glaciol., 46, 150-160 (doi: 10.3189/172756407782871512)

Hughes PD (2007) Recent behaviour of the Debeli Namet glacier, Durmitor, Montenegro. Earth Surf. Process. Landf., 32(10), 1593-1602 (doi: 10.1002/esp.1537)

Hughes PD (2009) Twenty-first century glaciers and climate in the Prokletije Mountains, Albania. Arct. Antarct. Alp. Res., 41(4), 455-459

Kääb A, Paul F, Maisch M, Hoelzle M and Haeberli W (2002) The new remote-sensing-derived Swiss glacier inventory: II. First results. Ann. Glaciol., 34, 362-366 (doi: 10.3189/ 172756402781817473)
Kaufmann V and Ladstädter R (2008) Documentation of the retreat of Gössnitzkees and Hornkees Glaciers (Hohe Tauern Range, Austria) for the time period 1997-2006 by means of aerial photogrammetry. In Hurni L and Kriz K eds. Proceedings of the 6th ICA Mountain Cartography Workshop: Mountain Mapping and Visualisation, 11-15 February 2008, Lenk, Switzerland. ETH Zürich, Zürich, 115-123

Kuhn M (1981) Climate and glaciers. IAHS Publ. 131 (Symposium at Canberra 1979 - Sea Level, Ice and Climatic Change), 3-20

Kuhn M (1994) Der Mieminger Schneeferner, ein Beispiel eines lawinenernährten Kartgletschers. Z. Gletscherkd. Glazialgeol., 29(2), 153-171

Kuhn M (1995) The mass balance of very small glaciers. Z. Gletscherkd. Glazialgeol., 31(1-2), 171-179

Lambrecht A and Kuhn M (2007) Glacier changes in the Austrian Alps during the last three decades, derived from the new Austrian glacier inventory. Ann. Glaciol., 46, 177-184 (doi: 10.3189/ 172756407782871341)

Meze D (1955) Ledenik na Triglavu in na Skuti. Geogr. Zbornik, 3, 10-114

Nadbath M (1999) Triglavski ledenik in spremembe podnebja [The Triglav Glacier and climate variations]. Ujma, 13, 24-29

Raper SCB and Braithwaite RJ (2009) Glacier volume response time and its links to climate and topography based on a conceptual model of glacier hypsometry. Cryosphere, 3(2), 183-194 (doi: 10.5194/tc-3-183-2009)

Rönnholm P, Hyyppä H, Pöntinen P, Haggrén $H$ and Hyyppä J (2003) A method for interactive orientation of digital images using backprojection of 3D data. Photogramm. J. Finl., 18(2), 16-31

Shahgedanova M, Nosenko G, Bushueva I and Ivanov M (2012) Changes in area and geodetic mass balance of small glaciers, Polar Urals, Russia, 1950-2008. J. Glaciol., 58(211), 953-964 (doi: 10.3189/2012JoG11J233)

Šifrer M (1963) Nova geomorfološka dognanja na Triglavu - Triglavski ledenik v letih 1954-1962. Geogr. Zbornik, 8, 157-210

Šifrer M and Košir D (1976) Poglavitna dognanja na Triglavskem ledeniku v letih 1963 do 1973. Geogr. Zbornik, 15, 213-240

Thibert E, Blanc R, Vincent C and Eckert N (2008) Glaciological and volumetric mass-balance measurements: error analysis over 51 years for Glacier de Sarennes, French Alps. J. Glaciol., 54(186), 522-532 (doi: 10.3189/002214308785837093)

Triglav-Čekada M (2007) Photogrammetrical monitoring of the Triglav Glacier in Slovenia. In Petrovič D ed. Proceedings of the 5th Mountain Cartography Workshop, 29 March-April 2006, Bohinj, Slovenia. Association of Surveyors of Slovenia/University of Ljubljana, Ljubljana, 242-248

Triglav-Čekada M, Radovan D, Gabrovec M and Kosmatin-Fras M (2011) Acquisition of the 3D boundary of the Triglav glacier from archived non-metric panoramic images. Photogramm. Rec., 26(133), 111-129 (doi: 10.1111/j.1477-9730.2011.00622.x)

Triglav-Čekada M, Zorn M, Kaufmann V and Lieb GK (2012) Measurements of small alpine glaciers: examples from Slovenia and Austria. Geodet. Vestnik, 56(3), 462-481

UNESCO/International Association of Scientific Hydrology (IASH) (1970) Perennial ice and snow masses: a guide for compilation and assemblage of data for a world inventory. (Technical Papers in Hydrology 1). UNESCO/IASH, Paris

Verbič T and Gabrovec M (2002) Georadarske meritve na Triglavskem ledeniku. Geogr. Vestnik, 74(1), 25-42 